\title{
The red wine phenolics piceatannol and myricetin act as agonists for estrogen receptor $\alpha$ in human breast cancer cells
}

\author{
M Maggiolini, A G Recchia, D Bonofiglio, S Catalano, A Vivacqua, A Carpino', V Rago1, \\ R Rossi and S Andò $\mathbf{1}$
}

Departments of Pharmaco-Biology and ${ }^{1}$ Cell Biology, University of Calabria, 87030 Rende (Cs), Italy

(Requests for offprints should be addressed to S Andò; Email: sebastiano.ando@unical.it)

\begin{abstract}
Previous epidemiological reports have suggested that red wine intake is associated with beneficial health effects due to the ability of certain phytochemical components to exert estrogen-like activity. It has been also documented that estrogens induce the proliferation of hormone-dependent breast cancer cells by binding to and transactivating estrogen receptor $(E R) \alpha$, which in turn interacts with responsive DNA sequences located within the promoter region of target genes. In order to provide further insight into the positive association between wine consumption and the incidence of breast carcinoma in postmenopausal women, we have evaluated the estrogenic properties of two abundant wine-derived compounds, named piceatannol (PIC) and myricetin (MYR), using as model systems the hormone-sensitive MCF7 and the endocrine-independent SKBR3 breast cancer cells. On the basis of our experimental evidence PIC and MYR may contribute to the estrogenicity of red wine since: (1) they transactivate endogenous ER $\alpha$; (2) they activate the agonist-dependent activation function (AF) 2 of ER $\alpha$ and $E R \beta$ in the context of the Gal4 chimeric proteins; (3) they rapidly induce the nuclear immunodetection of $E R \alpha$; (4) they regulate the expression of diverse estrogen target genes; (5) they compete with $17 \beta$-estradiol for binding to ER $\alpha$ and ER $\beta$; and - as a biological counterpart of the aforementioned abilities - (6) they exert stimulatory effects on the proliferation of MCF7 cells. Hence, the estrogenic activity of PIC and MYR might be considered at least as a potential factor in the association of red wine intake and breast tumors, particularly in postmenopausal women.
\end{abstract}

Journal of Molecular Endocrinology (2005) 35, 269-281

\section{Introduction}

Piceatannol (PIC; 3,5, 3' , $^{\prime}$-tetrahydroxy-trans-stilbene) and myricetin (MYR; 3,3', $4^{\prime}, 5,5^{\prime}, 7$-hexahydroxyflavone) (Fig. 1) are phenolic compounds that occur naturally in grapes and red wine (MacDonald et al. 1998, Teugo et al. 1998). The total amount of PIC and MYR in red-grape wines has been reported to be up to $15 \mathrm{mg} / \mathrm{l}$ (MacDonald et al. 1998, Burns et al. 2000, Vuorinen et al. 2000, Cantos et al. 2003), however the biotransformation of the abundant red wine component named resveratrol contributes to increase PIC concentrations at tissue level (Piver et al. 2004). Previous studies have demonstrated that PIC is a natural tyrosine kinase inhibitor (Geahlen \& McLaughlin 1989) exerting repressive effects in leukemia, melanomas and colorectal cancer cell lines (Wieder et al. 2001, Wolter et al. 2002, Larrosa et al. 2004), while MYR has been identified as a potent topoisomerase II repressor similar in activity to the epipodophyllotoxin widely used in cancer therapy (Markovits et al. 1989, Azuma et al. 1995, Chang et al. 1995). Several epidemiological investigations have suggested that the consumption of red wine is associated with a variety of health benefits due to the estrogenic activity of certain bioactive components (Stampfer et al. 1988, Frankel et al. 1993, Bertelli et al. 1995, Goldberg et al. 1995, Gronbaek et al. 1995, Pace-Asciak et al. 1995). It has been largely reported that $17 \beta-$ estradiol (E2) mainly acts by binding to and transactivating estrogen receptor (ER) $\alpha$ and $\operatorname{ER} \beta$, however different transduction pathways involved in the estrogen signaling have recently received a great deal of attention (Katzenellenbogen et al. 2000, Safe 2001, Maggiolini et al. 2004, Simoncini et al. 2004). A large body of evidence has demonstrated that E2 and E2-like compounds elicit stimulatory effects on breast cancer, the leading cause of tumor deaths among women in Western countries (Hoskins \& Weber 1994, Eisen \& Weber 1998, Lopez-Otin \& Diamandis 1998, Maggiolini et al. 2001). Therefore, much effort has been addressed to ascertain the ability of natural compounds to interact with $\mathrm{ER} \alpha$ and to trigger breast tumor progression. In this regard, it should be taken into account that wine consumption even in moderate amounts is directly associated with the 
<smiles>CC12CCC3c4ccc(O)cc4CCC3C1CCC2O</smiles>

\section{$17 \beta$-estradiol}<smiles>Oc1cc(O)cc(C=Cc2ccc(O)c(O)c2)c1</smiles>

Piceatannol<smiles>O=c1c(O)c(-c2cc(O)c(O)c(O)c2)oc2cc(O)cc(O)c12</smiles>

\section{Myricetin}

Figure 1 Chemical structures of $17 \beta$-estradiol, PIC and MYC. occurrence of breast carcinoma particularly in postmenopausal women (van den Brandt et al. 1995, Feigelson et al. 2001). Notably, in a multicentre Italian case-control study an increased risk of breast cancer was attributed to wine ingestion compared with other types of alcoholic beverages, explaining up to $12 \%$ of breast tumor cases in Italy (Ferraroni et al. 1998). In the present study, we have used as model systems the hormonesensitive MCF7 and endocrine-independent SKBR3 breast cancer cells in order to provide new insight into the molecular mechanisms by which the wine-derived PIC and MYR behave as estrogen-like compounds. In a concentration range physiologically achievable with a moderate wine consumption, both phytochemicals elicited growth stimulatory effects in MCF7 cells as a biological counterpart of their agonistic activity for ER $\alpha$.

\section{Materials and methods}

\section{Reagents}

E2, PIC, MYR and cycloheximide (Cx) were purchased from Sigma, while the ER antagonist ICI 182,780 (ICI) was obtained from Tocris Chemicals (Bristol, UK). Hydroxyflutamide (OHF) and ZK 98299 were a gift from Schering (Berlin, Germany). All compounds were solubilized in dimethylsulfoxide, except E2 which was dissolved in ethanol.

\section{Plasmids}

Firefly luciferase reporter plasmids used were XETL (Bunone et al. 1996) and TFF1/pS2-ERE (Berry et al. 1989) for the ERs and GK1 (Webb et al. 1998) for the Gal4 fusion proteins. The reporter plasmid XETL carries firefly luciferase sequences under the control of an estrogen response element (ERE) upstream of the thymidine kinase promoter. TFF1/pS2-ERE (a gift from V. Giguère, McGill University, Quebec City, Canada) contains the $\sim 1050 \mathrm{bp} \mathrm{TFF1/pS2}$ promoter preceding the luciferase reporter of pGL3 (Berry et al. 1989). As an internal transfection control, we co-transfected the plasmid pRL-CMV (Promega) that expresses renilla luciferase enzymatically distinguishable from firefly luciferase by the strong cytomegalovirus enhancer/ promoter. Gal4 chimeras Gal-ER $\alpha$, Gal-ER(V), GalER(R), Gal-ER(L), Gal-ER(543/4A), Gal-ER( $\Delta \mathrm{F})$ and Gal-ER $\beta$ were expressed from plasmids $\operatorname{GAL} 93 . \operatorname{ER}(\mathrm{G})$, GAL93.ER(V), GAL93.ER(R), GAL93.ER(L), GAL93.ER(ML543/4AA), GAL93. $\quad \mathrm{ER}(\Delta \mathrm{F})$ and GAL93.ER $\beta$ respectively. They were constructed by transferring the coding sequences for the hormonebinding domain (HBD) of ERa (amino acids 282-595) from HEG0 (Bunone et al. 1996), pCMVh ERG400 V (Aumais et al. 1997), pCMVhERG521R (Ekena et al. 1996), pCMVhERL525A (Ekena et al. 1996), a PCR- 
mutagenized intermediate with the point mutations M543A-L544A, a PCR fragment lacking the coding sequences for the $\mathrm{F}$ domain, and for the $\mathrm{ER} \beta \mathrm{HBD}$ (C-terminal 287 amino acids) from plasmid pCMV5hERbeta (a gift from J.-A. Gustafsson, Karolinska Institute, Huddinge, Sweden) respectively, into the mammalian expression vector pSCTEVGal93 (Siepel et al. 1992).

\section{Cell culture}

Wild-type ER $\alpha$-positive MCF7 human breast cancer cells were a gift from E. Surmacz (Sbarro Institute for Cancer Research and Molecular Medicine, Philadelphia, USA), the ER-negative SKBR3 human breast cancer cells and the ER $\alpha$-containing human uterine Ishikawa cells were a gift from D. Picard (Department of cell biology, University of Genève, Switzerland). MCF7 and Ishikawa cells were maintained respectively in Dulbecco's modified Eagle's medium (DMEM) or DMEM/F12 both without phenol red supplemented with 10\% fetal bovine serum (FBS) (Invitrogen); SKBR3 cells were maintained in RPMI 1640 without phenol red supplemented with 10\% FBS (Invitrogen).

\section{Transfections and luciferase assays}

A total of $10^{5}$ MCF7, SKBR3 and Ishikawa cells were transferred into 24-well plates with $500 \mu \mathrm{l}$ of regular growth medium/well the day before transfection. Medium lacking phenol red as well as serum was used on the day of transfection, which was performed by Fugene6 reagent (Roche) with a mixture containing $0.5 \mu \mathrm{g}$ reporter plasmid, $5 \mathrm{ng}$ pRL-GMV and $0 \cdot 1 \mu \mathrm{g}$ effector plasmid where applicable. After $6 \mathrm{~h}$, treatments were added and cells were incubated for a further 18-20 h. Luciferase activity was then measured with the Dual Luciferase Reporter Assay System (Promega) according to the manufacturer's recommendations. Firefly luciferase activity was normalized to the internal transfection control provided by renilla luciferase activity. Luciferase activity of cells receiving vehicle was set as 1-fold induction, upon which the results of treatments were calculated.

\section{RT-PCR}

MCF7 cells were grown in $10 \mathrm{~cm}$ dishes to about $60 \%$ confluence in regular growth medium and then were switched to medium lacking phenol red as well as serum for $24 \mathrm{~h}$. Thereafter, treatments were added for $24 \mathrm{~h}$ and mRNA expression was evaluated by semi-quantitative RT-PGR as we have previously described (Maggiolini et al. 1999). The primers for ER $\alpha$, estrogen-inducible trefoil factor TFF1/pS2 (Brown et al. 1984), cathepsin-D (Cavailles et al. 1991), estrogen-responsive RING finger protein (EFP) (Ikeda et al. 2000) as well as for the internal control acidic ribosomal phosphoprotein 36B4 (Laborda 1991) were: 5'AATTCAGATAATGGACGGCAG3' (ER $\alpha$ forward) and 5'GTGTTTCAACATTCTCGCT CGTC3' (ER $\alpha$ reverse);

5'TTCTATCGTAATACAATCGACG3' (pS2 forward) and

5'TTTGAGTAGTCAAAGTCAGAGC3' (pS2 reverse); 5'AACAACAGGGTGGGCTTC3' (cathepsin-D forward) and 5'ATGCACGAAACAGACTGTGC3' (cathepsin-D reverse);

5'CGTGTGGATTTGTGTGTGGACG3' (EFP forward) and 5'CGCGGAGGTGGAACTGAACC3' (EFP reverse);

5'GTGAAGATCTCGCGCTTCTC3' (36B4 forward) and

5'CAAATCGCATATCGTCGTCG3' (36B4 reverse); these primers yielded products of $345,210,303$, 162 and 400 bp with 20, 15, 20, 20 and 15 PCR cycles respectively.

\section{Western blotting}

MCF7 cells were grown in $10 \mathrm{~cm}$ dishes to about $60 \%$ confluence in regular growth medium and then were switched to medium lacking phenol red as well as serum for $24 \mathrm{~h}$. Thereafter, treatments were added for $24 \mathrm{~h}$ before lysis. In the case of $\mathrm{Cx}$, cells were pretreated for $3 \mathrm{~h}$ prior to the addition of ligands. Cells were lysed with $300 \mu \mathrm{l}$ of $50 \mathrm{mM}$ HEPES (pH 7.5), $150 \mathrm{mM} \mathrm{NaCl}$, $1.5 \mathrm{mM} \mathrm{MgCl}_{2}, 1 \mathrm{mM}$ EGTA, $10 \%$ glycerol, $1 \%$ Triton $\mathrm{X}-100,1 \% \mathrm{SDS}$, and a mixture of protease inhibitors containing $1 \mathrm{mM}$ aprotinin, $20 \mathrm{mM}$ phenylmethylsulfonyl fluoride and $0 \cdot 2 \mathrm{M}$ sodium orthovanadate. Equal amounts of whole protein extract were resolved on a $10 \%$ SDS-polyacrylamide gel, transferred to a nitrocellulose membrane (Amersham), probed overnight at $4{ }^{\circ} \mathrm{C}$ with the antibodies F-10 against $\mathrm{ER} \alpha$ and $\beta$-actin (both from Santa Cruz Biotechnology, CA, USA), and then revealed using the ECL System (Amersham).

\section{Immunocytochemical staining}

MCF7 cells were maintained in medium lacking phenol red as well as serum for 3 days, treated for $1 \mathrm{~h}$ and then fixed in fresh paraformaldehyde (PFA; $2 \%$ for $30 \mathrm{~min}$ ). After PFA removal, hydrogen peroxide (3\% in methanol for $30 \mathrm{~min}$ ) was used to inhibit endogenous peroxidase activity. Cells were then incubated with normal horse serum $(10 \%$ for $30 \mathrm{~min})$ to block the non-specific binding sites. Immunocytochemical staining was performed using as the primary antibody a mouse monoclonal immunoglobulin (Ig) $\mathrm{G}$ generated against the human C-terminus of ER $\alpha(\mathrm{F}-10$, Santa Cruz Biotechnology; 1:50 overnight at $4{ }^{\circ} \mathrm{C}$ ). A biotinylated horse-anti-mouse $\operatorname{IgG}(1: 600$ for $60 \mathrm{~min}$ at room 
temperature) was applied as the secondary antibody (Vector Laboratories, Burlingame, CA, USA). Subsequently, the amplification of avidin-biotin-horseradish peroxidase complex (ABC complex/HRP; Vector Laboratories; 1:100 for $30 \mathrm{~min}$ at room temperature) was carried out and 3,3'-diaminobenzidine tetrachloride dihydrate (Vector Laboratories) was used as a detection system. Cells were rinsed after each step with Trisbuffered saline $(0.05 \mathrm{M}$ Tris- $\mathrm{HCl}$ plus $0.15 \mathrm{M} \mathrm{NaCl}$, pH $7 \cdot 6$ ) containing $0 \cdot 05 \%$ Triton-X100 (TBS-T). In control experiments cells were processed replacing the primary antibody with mouse serum (Dako S.p.A., Milan, Italy) or using a primary antibody pre-absorbed $\left(48 \mathrm{~h}\right.$ at $\left.4{ }^{\circ} \mathrm{C}\right)$ with an excess of purified ER $\alpha$ protein (PanVera Corp., Madison, WI, USA).

\section{Ligand binding assay for ERs}

The ability of PIC and MYR to compete with $\left[{ }^{3} \mathrm{H}\right] \mathrm{E} 2$ for binding to $\mathrm{ER} \alpha$ and $\mathrm{ER} \beta$ was evaluated and compared with that of E2. Two picomoles of purified recombinant human ER $\alpha$ and ER $\beta$ proteins (PanVera Corp., Madison, WI, USA), each in $20 \mathrm{mM}$ HEPES, pH $7 \cdot 4,1.5 \mathrm{mM}$ EDTA, $0.5 \mathrm{mM}$ dithiothreitol and $10 \%$ (v/v) glycerol, were incubated with $1 \mathrm{nM}\left[2,4,6,7-{ }^{3} \mathrm{H}\right] \mathrm{E} 2$ (72 $\mathrm{Ci} / \mathrm{mmol}$; Amersham) in the presence of serial dilutions of unlabeled E2, PIC or MYR for 20-22 h at $4{ }^{\circ} \mathrm{C}$. Bound and free radioligands were separated on Sephadex G-25 PD-10 columns. The amount of receptor-bound $\left[{ }^{3} \mathrm{H}\right] \mathrm{E} 2$ was determined by liquid scintillation counting (OptiPhase, HiSafe 3 and 1409; Wallac, Inc., Gaithersburg, MD, USA). Relative counts per minute were plotted against the concentrations of the ligand, and data were evaluated with the use of a non linear, four-parameter logistic model to estimate the median effective concentration $\left(\mathrm{EC}_{50}\right)$ value.

\section{Proliferation assays}

For quantitative proliferation assays $1 \times 10^{4} \mathrm{MCF} 7$ cells were seeded in 24-well plates in regular growth medium. Cells were washed extensively once they had attached and were incubated in medium without serum for $24 \mathrm{~h}$. On the second day, the medium was changed and supplemented with 5\% charcoal-stripped (CS)-FBS. Ligands were added at this point, thereafter the 5\% CSS-FBS medium was renewed every day together with treatments. On day 6, cells were trypsinized and counted in a haemocytometer using the trypan blue exclusion method.

\section{Statistical analysis}

Statistical analysis was performed using ANOVA followed by Newman-Keuls testing to determine differences in means. Data are expressed as means \pm S.D. $P$ values $<0.05$ were considered significant.

\section{Results}

\section{Transactivation of the endogenous ER $\alpha$}

We first aimed to evaluate whether a transiently transfected ER reporter gene is able to respond to PIC and MYR. The reporter plasmid XETL carries firefly luciferase sequences under the control of an ERE upstream of the thymidine kinase promoter. As an internal transfection control, we co-transfected a plasmid that expresses renilla luciferase, which is enzymatically distinguishable from firefly luciferase, from the strong cytomegalovirus enhancer/promoter. Using MCF7 cells, which express ER $\alpha$ but no ER $\beta$ as judged by RT-PCR (data not shown), PIC and MYR were able to induce a substantial XETL expression from the concentration of $10 \mathrm{nM}$ (Fig. 2A). The ER antagonist ICI abolished the activation by E2 and both compounds (Fig. 3A), whereas the antiandrogen $\mathrm{OHF}$, the antiprogestin and antiglucocorticoid ZK 98299 had no effect (data not shown), suggesting that PIC and MYR transactivate $\mathrm{ER} \alpha$ directly. Next, using the natural pS2 EREcontaining promoter (Berry et al. 1989) we confirmed that both compounds were able to induce the ER $\alpha$-mediated transcriptional activity (Fig. 2B), which was no longer noticeable in the presence of ICI (Fig. 3B). For comparison, we performed the same transfection experiments in uterine Ishikawa cancer cells showing that PIC and MYR activated the endogenous ER $\alpha$ (Fig. 2C) in a direct manner since ICI inhibited the transcriptional response also in this cellular context (Fig. 3C).

\section{Activation of ER $\alpha$ and $E R \beta$ in a heterologous system}

To provide mechanistic evidence on the ability of PIC and MYR to transactivate ER $\alpha$ and to examine the response of $\operatorname{ER} \beta$, we turned to a heterologous system using SKBR3 cells lacking ERs. Chimeric proteins consisting of the DNA-binding domain (DBD) of the yeast transcription factor Gal4 and the ER $\alpha$ or the ER $\beta$ HBDs containing the ligand-dependent activation function $(\mathrm{AF}) 2$ were both activated by PIC and MYR although with a different potency compared with E2 (Fig. 4A). Hence, the HBD of each ER isoform was sufficient to allow the functional response, while the Gal4-DBD fused to the AF1 domain of ER $\alpha$ did not elicit transcriptional effects upon all treatments (Fig. 4B). Next, we examined the response of diverse ER $\alpha$ HBD mutants in the context of Gal4 proteins. The two-point mutations L525A and G521R that require a high E2 concentration for a substantial transactivation (Ekena et al. 1996) elicited very low activity upon PIC and MYR (Fig. 4B and C). The AF2 mutant M543/L544A failed to respond to all treatments (Fig. 4G), while the point mutation $\mathrm{G} 400 \mathrm{~V}$ and the mutant lacking the F-domain at the G-terminal HBD core exhibited a strong response 

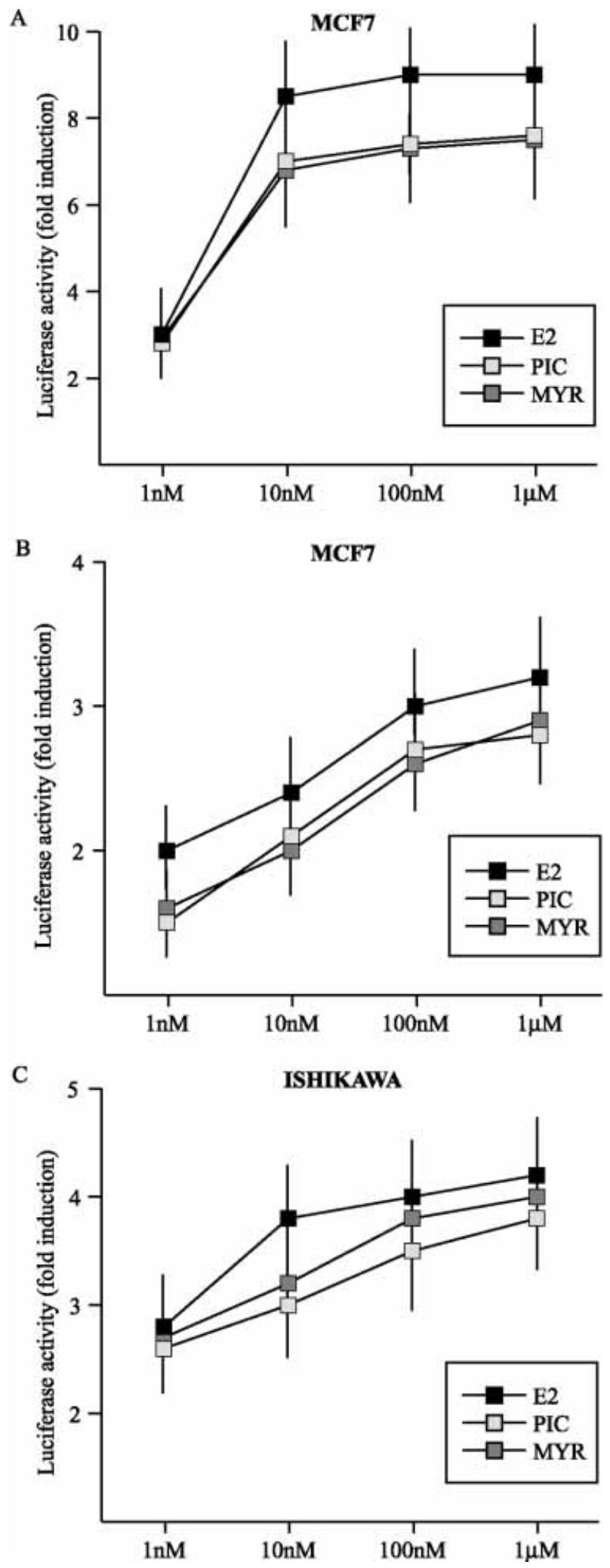

to E2, PIC and MYR (Fig. 4D). Taken together, our results argue that mutations of ER $\alpha$ in the hormone binding pocket are able to alter the transcriptional activity induced by E2 as well as that of the compounds tested.

\section{Nuclear immunolocalization of ERa}

Upon ligand binding, ER $\alpha$ undergoes conformational changes allowing the formation of receptor dimers and the interaction with specific EREs contained within the regulatory region of target genes (Tsai \& O'Malley 1994, Beato et al. 1996, Pratt \& Toft 1997). Performing an immunocytochemical assay we aimed to evaluate the ability of short PIC and MYR treatments $(1 \mathrm{~h})$ to elicit a nuclear localization of the endogenous $\mathrm{ER} \alpha$ in MCF7 cells. No detectable ER $\alpha$ immunoreactivity was observed in basal experimental conditions obtained by maintaining cells in medium lacking phenol red as well as serum for 3 days (Fig. 5). Only in the nuclear compartment did E2, PIC and MYR produce strong staining signals and these were abrogated in the presence of the ER antagonist ICI 182780 (Fig. 5). No signals were observed after replacing the anti-ER $\alpha$ antibody by irrelevant rabbit $\operatorname{IgG}$ or by using the primary antibody pre-absorbed with an excess of receptor protein (data not shown). These findings further supported the functional activity elicited by compounds tested in transfection experiments.

\section{Down-regulation of ER $\alpha$ mRNA and protein levels}

Levels of ER $\alpha$ in breast cancer cells are autoregulated by E2 through different mechanisms which include a reduced transcription rate of the ER $\alpha$ gene together with an increased turnover of the ligand-activated protein (Santagati et al. 1997). Hence, to evaluate whether PIC and MYR are also able to modulate the mRNA of ER $\alpha$ in MCF7 cells we performed a semiquantitative RT-PCR standardizing its expression by the housekeeping gene 36B4. Interestingly, both compounds induced a receptor down-regulation (Fig. 6A and $\mathrm{B}$ ) which was observed even at the protein level depending on new synthesis (Fig. 6C and D) (El Khissiin \& Leclercq 1999, Nonclercq et al. 2004).

Figure 2 PIC and MYR activate the endogenous ER $\alpha$. MCF7 breast cancer cells were transfected with the luciferase reporter plasmid XETL(A) or TFF1/pS2 (B) and treated with increasing concentrations of E2, PIC and MYR. (C) Uterine Ishikawa cancer cells were transfected as described for panel A. Luciferase activities were standardized to the internal transfection control and expressed as the ratio of induced activity to the activity in the absence of ligand. Each data point represents the mean of triplicate samples of three separate experiments. 
A

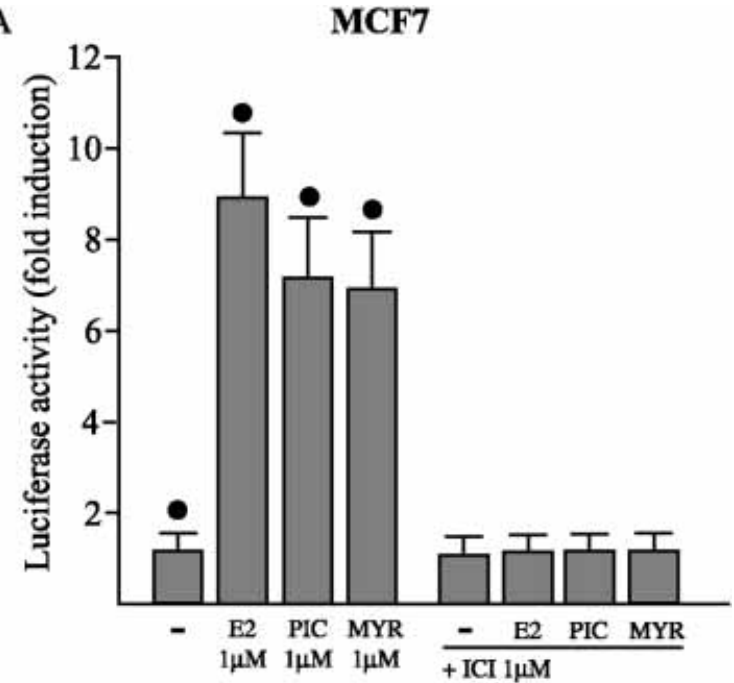

B

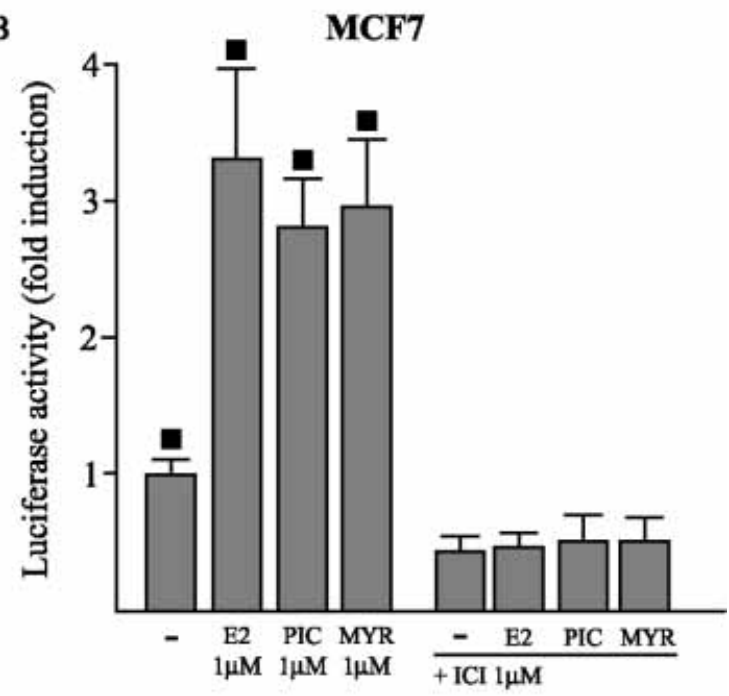

C

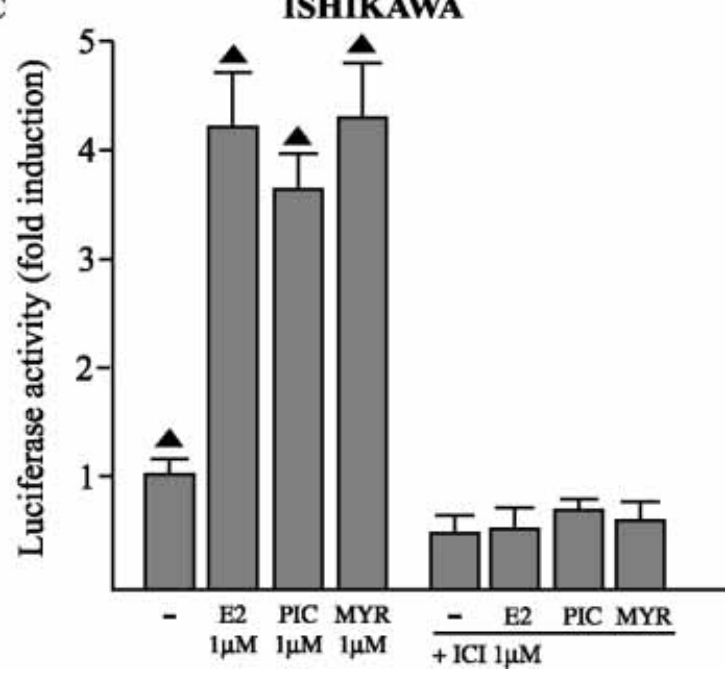

\section{Up-regulation of estrogen target genes}

As aforementioned, the E2/ER $\alpha$-activated complex regulates the expression of genes that contain ERE sequences within the promoter regions (Truss \& Beato 1993). Following the same experimental procedure described above, we documented the ability of PIC and MYR to up-regulate, like $\mathrm{E}_{2}$ the mRNA expression of target genes - such as pS2/TIFF1, cathepsin D and EFP E2, (Fig. 6A and B).

\section{Competition for ER binding}

The results obtained strongly suggested that PIC and MYR are ERs for ligands. This issue was examined directly by a competition binding experiment with purified recombinant human ER $\alpha$ and ER $\beta$ proteins. Our data demonstrated that both compounds compete with the radiolabeled E2 tracer for binding to the ERs in a concentration-dependent manner, however they are poor binders particularly for $\mathrm{ER} \alpha$ in comparison to $\mathrm{ER} \beta$ (Fig. 7). The latter phenomenon is in agreement with a previous report on ER isoform-specific preferences in binding to environmental estrogens (Kuiper et al. 1997).

\section{Proliferative effects on hormone-sensitive breast cancer cells}

Having clearly demonstrated that PIC and MYR are functional activators of $\mathrm{ER} \alpha$, we evaluated in a time course study the proliferative response of MCF7 cells to increasing concentrations of both ligands. Cells were lysed on the indicated days, counted in a hemocytometer, and results obtained upon treatments were compared with those of untreated cells. Notably, both compounds were able to induce progressive proliferative effects (Fig. 8A) which were no longer noticeable in presence of ICI (Fig. 8B), suggesting that even the growth stimulation is mediated by an ER $\alpha$-dependent mechanism.

\section{Discussion}

Our findings provide new insights into the activity exerted by the wine-derived phenolics PIC and MYR which can be considered ER agonists on the basis of their ability: (1) to activate endogenous ER $\alpha$ in hormone-dependent MCF7 and Ishikawa breast and uterine cancer cells respectively; (2) to activate the ligand-dependent AF2 domain of $\mathrm{ER} \alpha$ and $\mathrm{ER} \beta$ in the

Figure 3 The ER antagonist ICl inhibits the ER $\alpha$ transactivation by PIC and MYR. Cells were transfected with XETL ( $A$ and $C$ ) or with TFF1/pS2 ERE (B) and treated as indicated. Each data point represents the mean of triplicate samples of three separate experiments. $\boldsymbol{Q}, \boldsymbol{\Delta}, P<0.05$. 
A

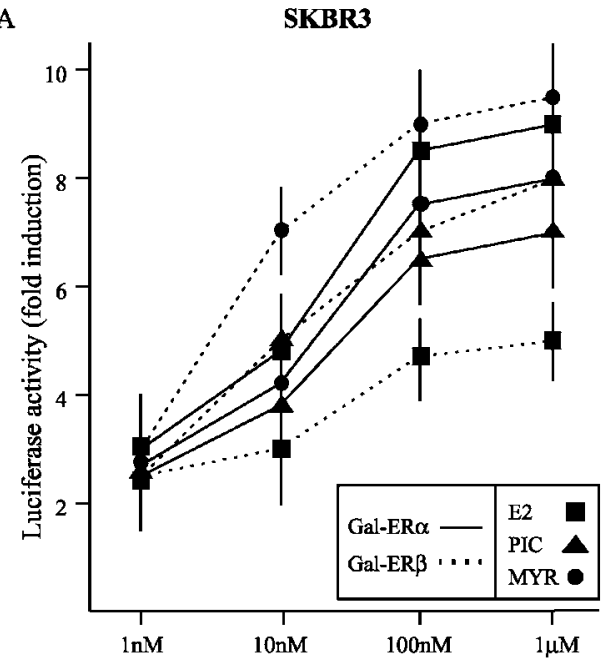

$\mathrm{C}$

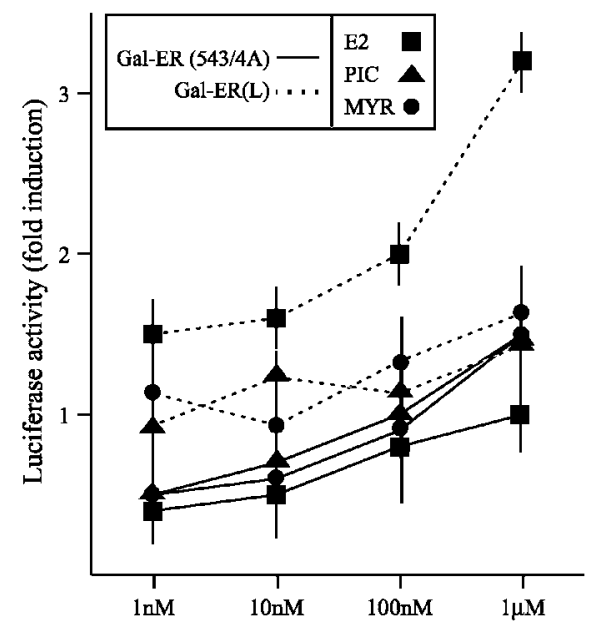

B

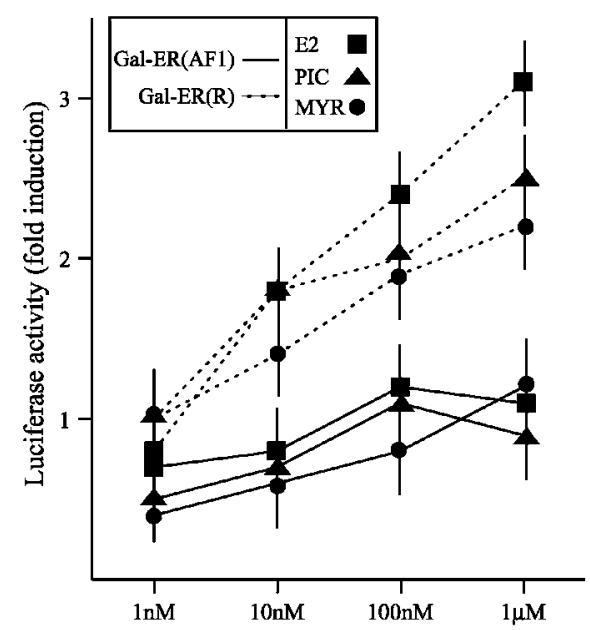

D

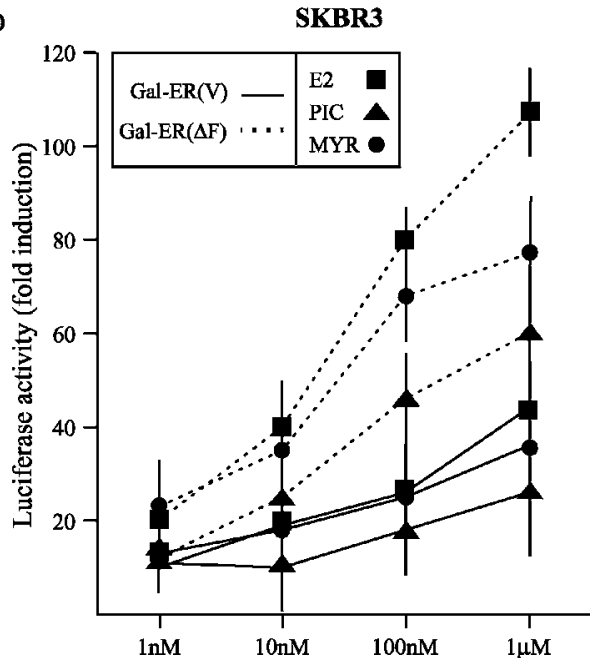

Figure 4 PIC and MYR are ER $\alpha$ and ER $\beta$ agonists in a heterologous system. Dose-response to E2, PIC and MYR of fusion proteins consisting of the Gal4-DBD and the ER $\alpha$ or ER $\beta$ HBD (A), the Gal4-DBD fused to the ER $\alpha$ AF1 domain and the Gal4-ER $\alpha$ HBD mutant G521R (B), the Gal4-ER $\alpha$ HBD mutants M543A-L544A and L525A (C), the Gal4-ER $\alpha$ HBD mutant G400 V and the Gal4-DBD fused to the ER $\alpha$ HBD lacking the F-domain (D) (see Materials and methods section for other details). Each data point represents the mean of triplicate samples of three separate experiments.

context of chimeric proteins with the Gal4 DBD in ER-negative SKBR3 breast cancer cells; (3) to elicit responses similar to E2 using different expression vectors for $\mathrm{ER} \alpha$ mutated in the AF2 domain; (4) to rapidly induce a nuclear immunodetection of ER $\alpha$; (5) to regulate $\mathrm{ER} \alpha$ mRNA and protein levels as well as the expression of estrogen target genes such as $\mathrm{TFF} 1 / \mathrm{pS}$, cathepsin D and EFP; (6) to compete with E2 for binding to purified $\mathrm{ER} \alpha$ and $\mathrm{ER} \beta$ proteins; (7) to stimulate the proliferation of MCF7 cells at concentrations that may be physiologically achievable through a moderate wine intake.
In recent years, the biological properties of natural estrogen-like compounds have attracted increasing interest for the potential beneficial effects on human health (Cotton 1994, Safe 1995, Lopez-Otin \& Diamandis 1998). In this regard, a reduced incidence and mortality from a variety of diseases has been associated with moderate wine consumption (Fuhrman et al. 1995, Goldberg et al. 1995, Whitehead et al. 1995, German \& Walzem 2000, Gronbaek et al. 2000), which is considered a relevant source of estrogenic compounds like the well-characterized resveratrol (Kopp 1998). In order to ascertain the mechanisms involved in the 

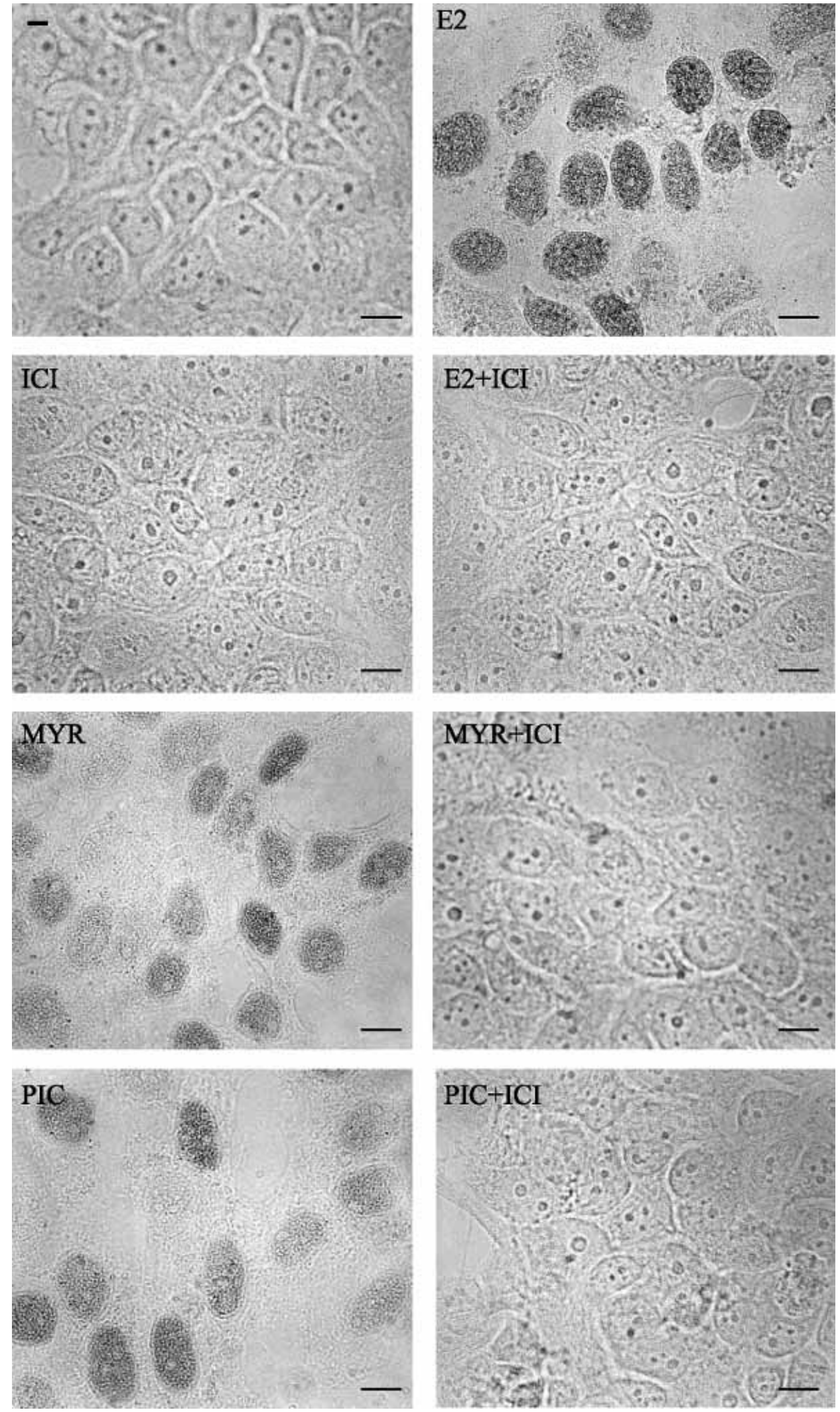

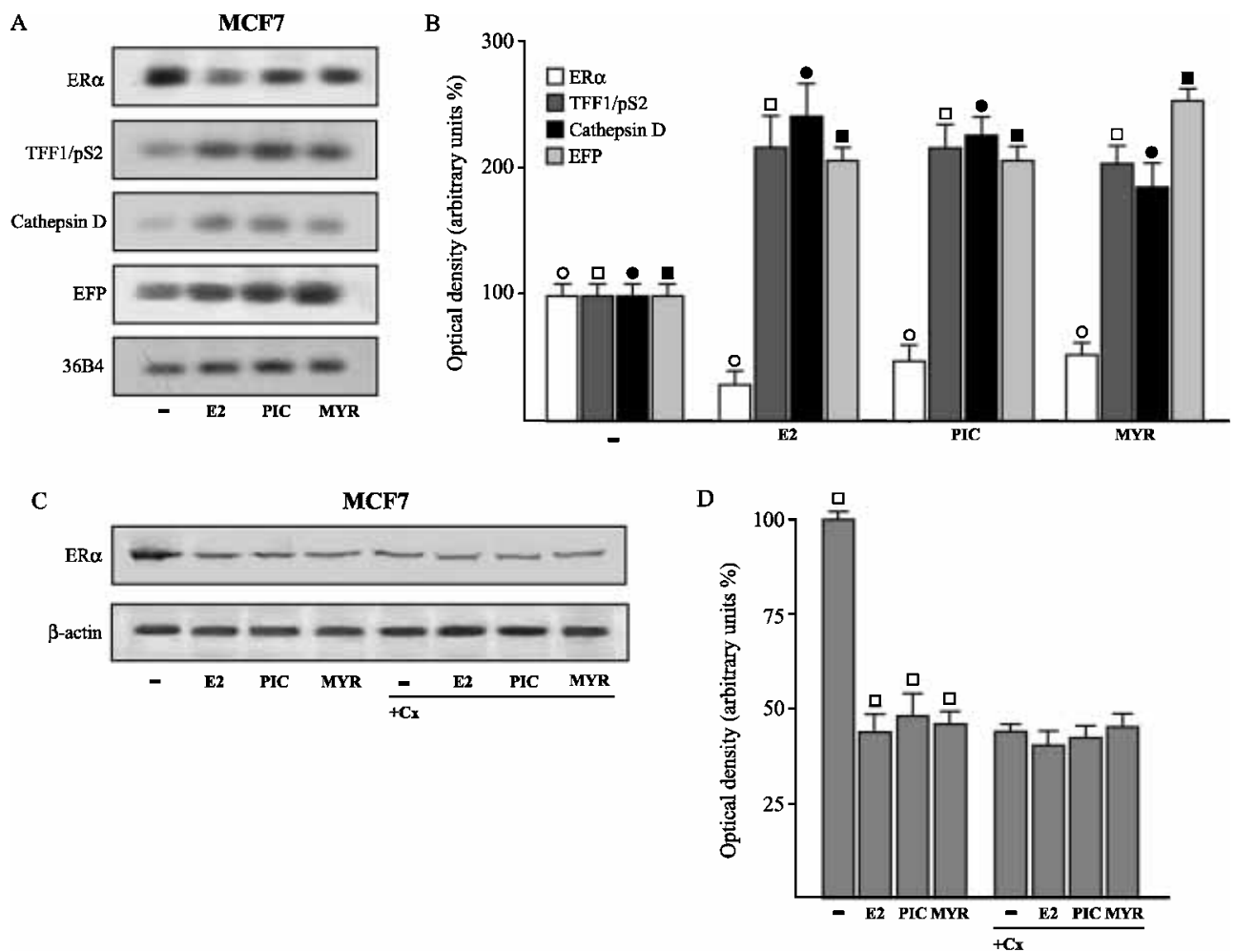

Figure $6 \mathrm{PIC}$ and MYR regulate the expression of estrogen target genes. (A) Semiquantitative RT-PCR of ER $\alpha$, TFF1/pS2, cathepsin D and EFP mRNA. MCF7 cells were stimulated for $24 \mathrm{~h}$ with $1 \mu \mathrm{M}$ E2, PIC and MYR; 36B4 mRNA levels served as a control. (B) Quantitative representation of data of two independent experiments including that of panel A after densitometry and correction for 36B4 expression. (C) Immunoblot of ER $\alpha$ from MCF7 cells treated for $24 \mathrm{~h}$ with $1 \mu \mathrm{M} \mathrm{E2,} \mathrm{PIC} \mathrm{and}$ MYR and $50 \mu \mathrm{M}$ Cx where applicable. (D) Quantitative representation of data of two independent experiments including that of panel $\mathrm{C}$ after densitometry. $\beta$-Actin served as a loading control. $\bigcirc, \square$, $\square, P<0.05$.

potential protective role exerted by resveratrol, many studies have been performed demonstrating its ability to regulate lipid metabolism and platelet function as well as to trigger apoptotic events in different cancer cells (Bagchi et al. 2001, Bianchini \& Vainio 2003, Pervaiz 2003). However, other investigations evaluating the potential estrogen-like properties of resveratrol have documented an agonistic activity for ER $\alpha$ including the ability to stimulate the proliferation of breast tumor cells (Gehm et al. 1997, Basly et al. 2000, Nakagawa et al. 2001, Levenson et al. 2003, Gehm et al. 2004). These findings are reminiscent of those reported for other abundant dietary flavonoids (Hsieh et al. 1998, Maggiolini et al. 2001 and references therein), and may suggest that the biological actions of resveratrol are either mediated by ER $\alpha$ or involve ER-independent mechanisms mainly in relationship to the cellular environment and levels of exposure (Gehm et al. 1997, Mgbonyebi et al. 1998, Ashby et al. 1999, Lu \& Serrero 1999, Bowers et al. 2000, Damianaki et al. 2000, Bhat et al. 2001). Hence, phytoestrogens and other natural compounds are potentially responsible for diverse pharmacological effects, which depend on bioavailability as well as metabolic clearance rates influencing consequently ER agonism/antagonism and even anticancer activity. In this respect, it is worth noting that resveratrol can undergo hydroxylation to yield PIC via different cytochrome P450 enzymes like CYP1B1 which has been found overexpressed in a wide variety of human tumors (Potter et al. 2002, Piver et al. 2004). Taking into account that PIC also derives directly from wine intake, we performed a panel of in vitro assays designed to better define its estrogen-like properties together with those of MYR, an additional phytochemical

Figure 5 Nuclear immunodetection of ER $\alpha$. MCF7 cells were serum deprived for 3 days and then treated for $1 \mathrm{~h}$ with vehicle $(-)$, $1 \mu \mathrm{M}$ E2, PIC, MYR and $1 \mu \mathrm{M}$ ER antagonist ICI where applicable. Each panel shown is representative of at least ten experiments. Scale bars, $5 \mu \mathrm{m}$. 

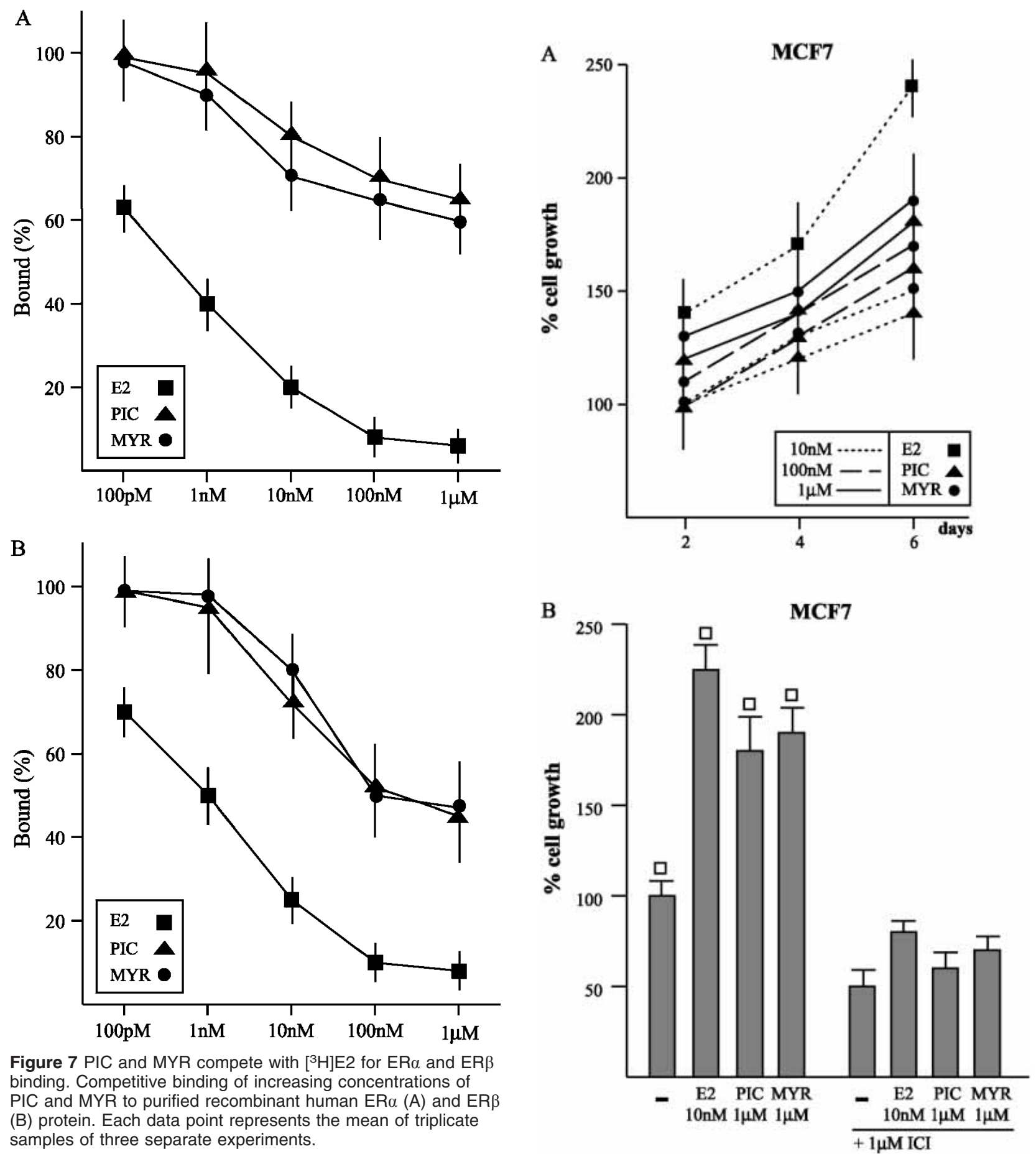

Figure $7 \mathrm{PIC}$ and MYR compete with [ $\left.{ }^{3} \mathrm{H}\right] \mathrm{E} 2$ for $\mathrm{ER} \alpha$ and $\mathrm{ER} \beta$ binding. Competitive binding of increasing concentrations of $\mathrm{PIC}$ and MYR to purified recombinant human ER $\alpha(\mathrm{A})$ and $\mathrm{ER} \beta$ (B) protein. Each data point represents the mean of triplicate samples of three separate experiments.

occurring abundantly in red wine. At a low concentration range physiologically achievable through wine consumption, both compounds stimulated the growth of hormone-sensitive breast tumor cells as ER $\alpha$ activators. Moreover, the results obtained in transfection experiments with Gal4 chimeras suggested that PIC and MYR

Figure $8 \mathrm{PIC}$ and MYR stimulate the proliferation of breast cancer cells. (A) Time- and dose-response study to PIC and MYR in MCF7 cells. Data obtained in cells after treatments were compared with those of vehicle-treated cells set as $100 \%$. (B) MCF7 cells were treated as indicated, lysed and counted on day 6 . Each data point represents the mean of triplicate samples of three separate experiments. $\square, P<0.05$. 
are AF2 agonists alongside other selective estrogen receptor modulators (SERMs) grouped as class I estrogens, according to the molecular classification previously proposed (Jordan et al. 2001). The ability of ligands to modulate intracellular levels of $\mathrm{ER} \alpha$ is important for ER $\alpha$ pharmacology. The human ER $\alpha$ is a substrate for ubiquitination in the presence of E2 and the exposure to different ligands has been shown to lower ER $\alpha$ levels by a proteosome-mediated proteolysis (Nawaz et al. 1999). The down-regulation of $\mathrm{ER} \alpha$ following treatments with PIC and MYR in MCF7 cells further supported their agonistic activity observed also through a ligand-dependent receptor degradation process. Moreover, despite a low binding affinity for $\mathrm{ER} \alpha$ both compounds up-regulated the expression profiles of diverse estrogen target genes providing a reliable assessment of the transcriptional efficacy exhibited in the context of natural DNA response elements.

A large body of evidence has suggested that ER $\alpha$-mediated estrogen signaling plays a major role in the etiology and progression of breast carcinoma (Ciocca \& Fanelli 1997, Lopez-Otin \& Diamandis 1998). Consequently, ER $\alpha$ antagonists have been extensively utilized as adjuvant endocrine treatment to prevent such malignancy and/or its recurrence (Early Breast Cancer Trialists Collaborative Group 1998, Cosman \& Lindsay 1999). However, about half of ER $\alpha$-positive tumors fail to respond to antiestrogen therapy from the beginning and most of the remaining ones eventually acquire pharmacological resistance. In this context, it should be noted that $\mathrm{E} 2$ and diverse phytoestrogens irrespective of ER expression trigger rapid genomic and non-genomic events (Brownson et al. 2002, Maggiolini et al. 2004) which, at least in part, contribute to the failure of antiestrogen treatment as well as to breast tumor progression. On the basis of the aforementioned observations and the present findings, the estrogenic properties of phytochemicals studied might be considered as a risk factor in postmenopausal women who habitually consume red wine (van den Brandt et al. 1995, Ferraroni et al. 1998, Feigelson et al. 2001, Poschl \& Seitz 2004). However, taking into account that PIC and MYR exert inhibitory effects in different tumor cells (Markovits et al. 1989, Azuma et al. 1995, Chang et al. 1995, Wieder et al. 2001, Wolter et al. 2002, Larrosa et al. 2004), their concentrations as well as the cellular context may direct various biological responses as has been previously reported for resveratrol and other phytoestrogens (Gehm et al. 1997, Hsieh et al. 1998, Basly et al. 2000, Maggiolini et al. 2001, Nakagawa et al. 2001, Bianchini \& Vainio 2003, Pervaiz 2003). Herein, we have provided mechanistic insight into the estrogenic potential of PIC and MYR that may be involved in the beneficial as well as the adverse effects associated with wine consumption. In this vein, further investigations are needed to elucidate the level of absorption and exposure to these phytochemicals, and the dose-dependent properties as well as the activity exerted in vivo in estrogen target tissues such as breast, uterus and bone.

\section{Funding}

This research was supported by grants from the Associazione Italiana per la Ricerca sal Cancrol (AIRC), Ministero dell' università e Ricerca Scientifica (MIUR), Regione Calabria (Italy). The authors declare that there is no conflict of interest that would prejudice the impartiality of this scientific work

\section{References}

Ashby J, Tinwell H, Pennie W, Brooks AN, Lefevre PA, Beresford N \& Sumpter JP 1999 Partial and weak oestrogenicity of the red wine constituent resveratrol: consideration of its superagonist activity in MCF-7 cells and its suggested cardiovascular protective effects. Fournal of Applied Toxicology 19 39-45.

Aumais JP, Lee HS, Lin R \& White JH 1997 Selective interaction of hsp90 with an estrogen receptor ligand-binding domain containing a point mutation. Fournal of Biological Chemistry 272 12229-12235.

Azuma Y, Onishi Y, Sato Y \& Kizaki H 1995 Effects of protein tyrosine kinase inhibitors with different modes of action on topoisomerase activity and death of IL-2-dependent CTLL-2 cells. Fournal of Biochemistry 118 312-318.

Bagchi D, Das DK, Tosaki A, Bagchi M \& Kothari SC 2001 Benefits of resveratrol in women's health. Drugs under Experimental and Clinical Research 27 233-248.

Basly JP, Marre-Fournier F, Le Bail JC, Habrioux G \& Chulia AJ 2000 Estrogenic/antiestrogenic and scavenging properties of (E)and (Z)-resveratrol. Life Sciences 66 769-777.

Beato M, Truss M \& Chavez S 1996 Control of transcription by steroid hormones. Annals of the New York Academy of Sciences $\mathbf{7 8 4}$ 93-123.

Berry M, Nunez A-M \& Chambon P 1989 Estrogen-responsive element of the human $\mathrm{pS} 2$ gene is an imperfectly palindromic sequence. PNAS 86 1218-1222.

Bertelli AA, Giovannini L, Giannessi D, Migliori M, Bernini W, Fregoni M \& Bertelli A 1995 Antiplatelet activity of synthetic and natural resveratrol in red wine. International fournal of Tissue Reactions 17 1-3.

Bhat KP, Lantvit D, Christov K, Mehta RG, Moon RG \& Pezzuto JM 2001 Estrogenic and antiestrogenic properties of resveratrol in mammary tumor models. Cancer Research 61 7456-7463.

Bianchini F \& Vainio H 2003 Wine and resveratrol: mechanisms of cancer prevention? European Fournal of Cancer Prevention 5 417-425.

Bowers JL, Tyulmenkov VV, Jernigan SC \& Klinge CM 2000 Resveratrol acts as a mixed agonist/antagonist for estrogen receptors alpha and beta. Endocrinology 141 3657-3667.

Brown AM, Jeltsch JM, Roberts M \& Chambon P 1984 Activation of $\mathrm{pS} 2$ gene transcription is a primary response to estrogen in the human breast cancer cell line MCF-7. PNAS $816344-6348$.

Brownson DM, Azios NG, Fuqua BK, Dharmawardhane SF \& Mabry TJ 2002 Flavonoid effects relevant to cancer. Fournal of Nutrition 132 3482S-3489S

Bunone G, Briand PA, Miksicek RJ \& Picard D 1996 Activation of the unliganded estrogen receptor by EGF involves the MAP kinase pathway and direct phosphorylation. EMBO foumal 15 2174-2183. 
Burns J, Gardner PT, O’Neil J, Crawford S, Morecroft I, McPhail DB, Lister C, Matthews D, MacLean MR, Lean ME, Duthie GG \& Crozier A 2000 Relationship among antioxidant activity, vasodilation capacity, and phenolic content of red wines. Fournal of Agricultural and Food Chemistry 48 220-230.

Cantos E, Espin JC, Fernandez MJ, Oliva J \& Tomas-Barberan FA 2003 Postharvest UV-C-irradiated grapes as a potential source for producing stilbene-enriched red wines. Fournal of Agricultural and Food Chemistry 51 1208-1214.

Cavailles V, Augereau P \& Rochefort H 1991 Cathepsin D gene of human MCF7 cells contains estrogen-responsive sequences in its $5^{\prime}$ proximal flanking region. Biochemical and Biophysical Research Communications 174 816-824.

Chang YC, Nair MG \& Nitiss JL 1995 Metabolites of daidzein and genistein and their biological activities. Fournal of Natural Products 58 1901-1905.

Ciocca DR \& Fanelli MA 1997 Estrogen receptors and cell proliferation in breast cancer. Trends in Endocrinology and Metabolism 8 313-321.

Cosman F \& Lindsay R 1999 Selective estrogen receptor modulators: clinical spectrum. Endocrine Reviewes 20 418-434.

Cotton P 1994 Environmental estrogenic agents area of concern. JAMA 271414416

Damianaki A, Bakogeorgou E, Kampa M, Notas G, Hatzoglou A, Panagiotou S, Gemetzi C, Kouroumalis E, Martin PM \& Castanas E 2000 Potent inhibitory action of red wine polyphenols on human breast cancer cells. Fournal of Cellular Biochemistry 78 429-441.

Early Breast Cancer Trialists Collaborative Group 1998 Tamoxifen for early breast cancer: an overview of the randomized trials. Lancet 351 1451-1467.

Eisen A \& Weber BL 1998 Recent advances in breast cancer biology. Current Opinion in Oncology 10 486-491.

Ekena K, Weis KE, Katzenellenbogen JA \& Katzenellenbogen BS 1996 Identification of amino acids in the hormone binding domain of the human estrogen receptor important in estrogen binding. Fournal of Biological Chemistry 271 20053-20059.

El Khissiin A \& Leclercq G 1999 Implication of proteasome in estrogen receptor degradation. FEBS Letters 448 160-166.

Feigelson HS, Calle EE, Robertson AS, Wingo PA \& Thun MJ 2001 Alcohol consumption increases the risk of fatal breast cancer (United States). Cancer Causes and Control 12 895-902.

Ferraroni M, Decarli A, Franceschi S \& La Vecchia C 1998 Alcohol consumption and risk of breast cancer: a multicentre Italian case-control study. European Fournal of Cancer 34 1403-1409.

Frankel EN, Waterhouse AL \& Kinsella JE 1993 Inhibition of human LDL oxidation by resveratrol. Lancet 341 1103-1104.

Fuhrman B, Lavy A \& Aviram M 1995 Consumption of red wine with meals reduces the susceptibility of human plasma and low-density lipoprotein to lipid peroxidation. American fournal of Clinical Nutrition $61549-554$.

Geahlen RL \& McLaughlin JL 1989 Piceatannol (3,4,3',5'tetrahydroxy-trans-stilbene) is a naturally occurring proteintyrosine kinase inhibitor. Biochemical and Biophysical Research Communications 165 241-245.

Gehm BD, McAndrews JM, Chien PY \& Jameson JL 1997 Resveratrol, a polyphenolic compound found in grapes and wine, is an agonist for the estrogen receptor. PNAS $\mathbf{9 4}$ 14138-14143.

Gehm BD, Levenson AS, Liu H, Lee EJ, Amundsen BM, Cushman M, Jordan VC \& Jameson JL 2004 Estrogenic effects of resveratrol in breast cancer cells expressing mutant and wild-type estrogen receptors: role of AF1 and AF2. Fournal of Steroid Biochemistry and Molecular Biology 88 223-234.

German JB \& Walzem RL 2000 The health benefits of wine. Annual Review of Nutrition 20 561-593.

Goldberg DM, Hahn SE \& Parkes JG 1995 Beyond alcohol: beverage consumption and cardiovascular mortality. Clinica Chimica Acta; International fournal of Clinical Chemistry 237 155-187.
Gronbaek M, Deis A, Sorensen TIA, Becker U, Schnohr P \& Jensen G 1995 Mortality associated with moderate intakes of wine, beer or spirits. British Medical Fournal $\mathbf{3 1 0} 1165$.

Gronbaek M, Becker U, Johansen D, Gottschau A, Schnohr P, Hein HO, Jensen G \& Sorensen TI 2000 Type of alcohol consumed and mortality from all causes, coronary heart disease, and cancer. Annals of Internal Medicine 133 411-419.

Hoskins K \& Weber BL 1994 The biology of breast cancer. Current Opinion in Oncology 6 554-559.

Hsieh CY, Santell RC, Haslam SZ \& Helferich WG 1998 Estrogenic effects of genistein on the growth of estrogen receptor-positive human breast cancer (MCF-7) cells in vitro and in vivo. Cancer Research 58 3833-3838.

Ikeda K, Orimo A, Higashi Y, Muramatsu M \& Inoue S 2000 Efp as a primary estrogen-responsive gene in human breast cancer. FEBS Letters 472 9-13.

Jordan VC, Schafer JM, Levenson AS, Liu H, Pease KM, Simons LA \& Zapf JW 2001 Molecular classification of estrogens. Cancer Research 61 6619-6623.

Katzenellenbogen BS, Choi I, Delage-Mourroux R, Ediger TR, Martini PG, Montano M, Sun J, Weis K \& Katzenellenbogen JA 2000 Molecular mechanisms of estrogen action: selective ligands and receptor pharmacology. Fournal of Steroid Biochemistry and Molecular Biology 74 279-285.

Kopp P 1998 Resveratrol, a phytoestrogen found in red wine. A possible explanation for the conundrum of the 'French paradox'? European Fournal of Endocrinology 138 619-620.

Kuiper GGJM, Carlsson B, Grandien K, Enmark E, Haggblad J, Nilsson S \& Gustafsson JA 1997 Comparison of the ligand binding specificity and transcript tissue distribution of estrogen receptor alpha and beta. Endocrinology 138 863-870.

Laborda J 1991 36B4 cDNA used as an estradiol-independent mRNA control is the cDNA for human acidic ribosomal phosphoprotein PO. Nucleic Acids Research 193998.

Larrosa M, Tomas-Barberan FA \& Espin JC 2004 The grape and wine polyphenol piceatannol is a potent inducer of apoptosis in human SK-Mel-28 melanoma cells. European Fournal of Nutrition $\mathbf{4 3}$ 275-284.

Levenson AS, Gehm BD, Pearce ST, Horiguchi J, Simons LA, Ward LE III, Jameson JL \& Jordan VC 2003 Resveratrol acts as an estrogen receptor (ER) agonist in breast cancer cells stably transfected with ER $\alpha$. International fournal of Cancer 104 587-596.

Lopez-Otin C \& Diamandis EP 1998 Breast and prostate cancer: an analysis of common epidemiological, genetic, and biochemical features. Endocrine Reviews 19 365-396.

Lu R \& Serrero G 1999 Resveratrol, a natural product derived from grape, exhibits antiestrogenic activity and inhibits the growth of human breast cancer cells. Fournal of Cellular Physiology 179 297-304.

McDonald MS, Hughes M, Burns J, Lean ME, Matthews D \& Crozier A 1998 Survey of the free and conjugated myricetin and quercetin content of red wines of different geographical origins. Fournal of Agricultural and Food Chemistry 46 368-375.

Maggiolini M, Donzé O \& Picard D 1999 A non-radioactive method for inexpensive quantitative RT-PCR. Biological Chemistry 380 695-697.

Maggiolini M, Bonofiglio D, Marsico S, Panno ML, Cenni B, Picard D \& Andò S 2001 Estrogen receptor alpha mediates the proliferative but not the cytotoxic dose-dependent effects of two major phytoestrogens on human breast cancer cells. Molecular Pharmacololgy 60 595-602.

Maggiolini M, Vivacqua A, Fasanella G, Recchia AG, Sisci D, Pezzi V, Montanaro D, Musti AM, Picard D \& Andò S 2004 The G protein-coupled receptor GPR30 mediates c-fos up-regulation by 17 beta-estradiol and phytoestrogens in breast cancer cells. Fournal of Biological Chemistry 279 27008-27016.

Markovits J, Linassier C, Fosse P, Couprie J, Pierre J, JacqueminSablon A, Saucier JM, Le Pecq JB \& Larsen AK 1989 Inhibitory 
effects of the tyrosine kinase inhibitor genistein on mammalian DNA topoisomerase II. Cancer Research 49 5111-5117.

Mgbonyebi OP, Russo J \& Russo IH 1998 Antiproliferative effect of synthetic resveratrol on human breast epithelial cells. International Fournal of Oncology 12 865-869.

Nakagawa H, Kiyozuka Y, Uemura Y, Senzaki H, Shikata N, Hioki K \& Tsubura A 2001 Resveratrol inhibits human breast cancer cell growth and may mitigate the effect of linoleic acid, a potent breast cancer cell stimulator. Fournal of Cancer Research and Clinical Oncology 127 258-264.

Nawaz Z, Lonard DM, Dennis AP, Smith CL \& O'Malley BW 1999 Proteosome-dependent degradation of the human estrogen receptor. PNAS 96 1858-1862.

Nonclercq D, Journe F, Body JJ, Leclercq G \& Laurent G 2004 Ligand-independent and agonist-mediated degradation of estrogen receptor-alpha in breast carcinoma cells: evidence for distinct degradative pathways. Molecular and Cellular Endocrinology 227 53-65.

Pace-Asciak CR, Hahn S, Diamandis EP, Soleas G \& Goldberg DM 1995 The red wine phenolics trans-resveratrol and quercetin block human platelet aggregation and eicosanoid synthesis: implications for protection against coronary heart disease. Clinica Chimica Acta; International Fournal of Clinical Chemistry 235 207-211.

Pervaiz S 2003 Resveratrol: from grapevines to mammalian biology. FASEB Fournal 14 1975-1985.

Piver B, Fer M, Vitrac X, Merillon JM, Dreano Y, Berthou F \& Lucas D 2004 Involvement of cytochrome P450 1A2 in the biotransformation of trans-resveratrol in human liver microsomes. Biochemical Pharmacology 68 773-782.

Poschl G \& Seitz HK 2004 Alcohol and cancer. Alcohol and Alcoholism 39 155-165.

Potter GA, Patterson LH, Wanogho E, Perry PJ, Butler PC, Ijaz T, Ruparelia KC, Lamb JH, Farmer PB, Stanley LA \& Burke MD 2002 The cancer preventive agent resveratrol is converted to the anticancer agent piceatannol by the cytochrome P450 enzyme CYP1B1. British Fournal of Cancer 86 774-778.

Pratt WB \& Toft DO 1997 Steroid receptor interactions with heat shock protein and immunophilin chaperones. Endocrine Reviewes $\mathbf{1 8}$ 306-360.

Safe S 2001 Transcriptional activation of genes by 17 beta-estradiol through estrogen receptor-Spl interactions. Vitamins and Hormones 62 231-252.

Safe SH 1995 Environmental and dietary estrogens and human health: is there a problem? Environmental Health Perspectives $\mathbf{1 0 3}$ 346-351

Santagati S, Gianazza E, Agrati P, Vegeto E, Patrone C, Pollio G \& Maggi A 1997 Oligonucleotide squelching reveals the mechanism of estrogen receptor autologous down-regulation. Molecular Endocrinology 7 938-949.
Seipel K, Georgiev O \& Shaffner W 1992 Different activation domains stimulate transcription from remote (enhancer) and proximal (promoter) positions. EMBO Journal 11 4961-4968.

Simoncini T, Mannella P, Fornari L, Caruso A, Varone G \& Genazzani AR 2004 Genomic and non-genomic effects of estrogens on endothelial cells. Steroids $69537-542$.

Stampfer MJ, Colditz GA, Willets WC, Speizer FE \& Hennekens CH 1988 A prospective study of moderate alcohol consumption and the risk of coronary heart disease and stroke in women. New England Joumal of Medicine $\mathbf{3 1 9} 267$.

Teugo PW, Fauconneau B, Deffieux G, Huguet F, Vercauteren J \& Merillon JM 1998 Isolation, identification, and antioxidant activity of three stilbene glucosides newly extracted from Vitis vinifera cell cultures. Fournal of Natural Products 61 655-657.

Truss M \& Beato M 1993 Steroid hormone receptors: interaction with deoxyribonucleic acid and transcription factors. Endocrine Reviewes 14 459-479.

Tsai MJ \& O'Malley B 1994 Molecular mechanisms of action of steroid/thyroid receptor superfamily members. Annual Review of Biochemistry 63 451-486.

van den Brandt PA, Goldbohm RA \& van't Veer P 1995 Alcohol and breast cancer: results from The Netherlands Cohort Study. American Fournal of Epidemiology 141 907-915.

Vuorinen H, Maatta K \& Torronen R 2000 Content of the flavonols myricetin, quercetin, and kaempferol in finnish berry wines. Fournal of Agricultural and Food Chemistry 48 2675-2680.

Webb P, Nguyen P, Shinsako J, Anderson C, Feng W, Nguyen MP, Chen D, Huang SM, Subramanian S, McKinerney E, Katzenellenbogen BS, Stallcup MR \& Kushner PJ 1998 Estrogen receptor activation function 1 works by binding pl60 coactivator proteins. Molecular Endocrinology 12 1605-1618.

Whitehead TP, Robinson D, Allaway S, Syms J \& Hale A 1995 Effect of red wine ingestion on the antioxidant capacity of serum. Clinical Chemistry 41 32-35.

Wieder T, Prokop A, Bagci B, Essmann F, Bernicke D, Shulze-Osthoff K, Dorken B, Schmalz HG, Daniela PT \& Henze G 2001 Piceatannol, a hydroxylated analog of the chemopreventive agent resveratrol, is a potent inducer of apoptosis in the lymphoma cell line $\mathrm{BJAB}$ and in primary leukemic lymphoblasts. Leukemia 15 1735-1742.

Wolter F, Clausnitzer A, Akoglu B \& Stein J 2002 Piceatannol, a natural analog of resveratrol, inhibits progression through the $S$ phase of the cell cycle in colorectal cell lines. Fournal of Nutrition 132 298-302.

Received 26 April 2005

Accepted 13 June 2005

Made available online as accepted preprint 8 July 2005 